\title{
Coronavirus Disease (COVID-19) in Nigeria: Mitigating the Global Pandemic
}

\author{
Olayinka R. Ibrahim ${ }^{1}$, Yetunde T. Olasinde ${ }^{2}$
}

${ }^{1}$ Department of Paediatrics, Federal Medical Centre, Katsina, Nigeria

${ }^{2}$ Department of Paediatrics, Bowen University, Iwo and Bowen University Teaching Hospital, Ogbomoso, Nigeria

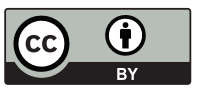

This work is licensed under a Creative Commons Attribution 4.0 International License

Received: 2020-03-06

Accepted: 2020-03-15

UDC: 618.1

J Clin Med Kaz 2020; 1(55):36-38

Corresponding Author: Dr. Olayinka R. IBRAHIM, Department of Paediatrics, Federal Medical Centre, Along Jibya Bypass, Katsina, Nigeria.

Tel.: +234-806-6188-403

E-mail: ibroplus@gmail.com

\section{Abstract}

The confirmation of Covid-19 in Nigeria is not unexpected given the global spread of the disease that originated from China. With an estimated 200 million people and an infectious disease vulnerability index of 0.27 , a poorly managed case of Covid-19 may worsen the global pandemic. Hence, we examined the peculiarities of Nigeria as a nation and suggested ways of curtailing further spread of the disease in the country.

Key words: coronavirus disease, Covid-19, Nigeria, global pandemic

\section{НИГЕРИЯДАҒЫ КОРОНАВИРУСТЫҚ ИНФЕКЦИЯ (COVID-19): ҒАЛАМДЫК ПАНДЕМИЯ САЛДАРЫНЫН ӘЛСІРЕУІ}

\section{О.Р. Ибрахим ${ }^{1}$, Е.Т. Оласиндэ ${ }^{2}$}

'Педиатрия бөлімі, Федералды медицина орталығы Кацина, Нигерия

${ }^{2}$ Педиатрия бөлімі, Боуэн унивесртитеті, Иво және Боуэн университеттік оку ауруханасы, Огбомошо, Нигерия

\section{ТҰЖЫРЫМДАМА}

Қытайда пайда болған аурудың ғаламдық таралуын ескерсек, Нигерияда COVID-19-дың расталуы күтпеген жағдай емес. Шамамен 200 миллион адамы бар және жұқпалы ауруларға бейімділік индексі 0,27 болса, нашар реттелген COVID-19 жағдайы жаһандық пандемияны ушықтыруы мүмкін. Сондықтан біз Нигерияның ұлт ретінде сипаттамаларын зерттеп, елде бұл аурудың одан әрі таралуын болдырмау жолдарын ұсындық.

Негізгі сөздер: коронавирус инфекциясы, COVID-19, Нигерия, ғаламдық пандемия

\section{КОРОНАВИРУСНАЯ ИНФЕКЦИЯ (COVID-19) В НИГЕРИИ: СМЯГЧЕНИЕ ПОСЛЕДСТВИЙ ГЛОБАЛЬНОЙ \\ ПАНДЕМИИ}

О.Р. Ибрахим ${ }^{1}$ Е.Т. Оласиндэ²

'Отделение педиатрии, Федеральный медицинский центр, Кацина, Нигерия

${ }^{2}$ Отделение педиатрии, Университет Боуэн, Университетская учебная больница Иво и Боуэн,Огбомошо, Нигерия

\section{РЕЗЮМЕ}

Подтверждение Covid-19 в Нигерии не является неожиданным, учитывая глобальное распространение болезни, которая появилась в Китае. Численностью примерно в 200 миллионов человек и индексом уязвимости к инфекционным заболеваниям в 0,27, слабо регулируемый случай с Covid-19 может усугубить глобальную пандемию. Поэтому мы рассмотрели особенности Нигерии как нации и предложили пути сдерживания дальнейшего распространения этой болезни в стране.

Ключевые слова: коронавирусная инфекция, Covid-19, Нигерия, глобальная пандемия 


\section{Introduction}

Coronavirus disease renamed (Covid-19) by the World Health Organisation (WHO) has been ravaging the world in the past two months [1]. The novel virus first reported from Wuhan, Hubei Province in China with link to the Huanan Seafood wholesale live animal market (presently closed down) is now present in six continents except the Antarctica as of 27th February 2020 [2], [3]. Over a period of eight weeks, the Covid-19 has spread to 58 countries. The WHO situation report (1st March 2020) indicated 87,137 confirmed cases with 2977 deaths, making the outbreak the worst in decades [3]. Despite the promptness of the Chinese government to limit the spread through a well-coordinated effort, there are reports of new cases outside China daily [4-5]. Thus, few African countries have reported cases of Covid-19 (Algeria and Egypt had a case each), and more recently, Nigeria confirmed a new case on the 27th February 2020 [6]. The response of the Chinese government ranked among the best in the recent times, with a similar effort in most parts of Europe. In contrast, Nigeria having a very low score of 0.27 out of a maximum of 1.0 in the "Infectious Disease Vulnerability Index" ranking, a poorly managed outbreak may worsen the global pandemic [7]. Hence, we examined the peculiarities of the country in the light of the first confirmed case, reviewed the clinical features of the disease and suggested the ways of mitigating the global pandemic at the country level.

\section{Clinical features}

The first study on the clinical presentation of Covid-19 infected patients indicated the most frequent presentations as fever, cough, and dyspnoea [8]. Also, most patients were adults; with a male preponderance and higher mortality in those with underlying chronic medical conditions. Subsequent studies on the profile of the infected patients corroborated earlier observations in those with Covid-19 [9-10]. The earlier studies showed a strong linkage to the Wuhan wholesale live animal market; however, recent studies showed no direct linkage with Wuhan market, confirming the possibility of human to human transmission [10]. Surprisingly, there are few reported cases in children with the two studies indicating no childhood infection [8-9]. A review of 1099 infected people in China showed only nine children out of over a thousand with Covid-19 infection with no death [10]. Whereas, the clinical features of symptomatic individuals are apparent, including symptoms that aid in the case definition, there are few asymptomatic individuals [10]. The asymptomatic people with Covid-19 are capable of spreading the infection and may pose a challenge to the epidemiological control. It is also of note that clinical features documented among the Chinese patients are similar to symptoms of respiratory illnesses in Africa, which may pose the challenge of prompt recognition in the event of a massive outbreak in Nigeria.

\section{Contact tracing and isolation}

With an estimated population of 200 million people and Infectious Disease Vulnerability Index of 0.27 , a single case of Covid-19 in Nigeria needs proactive steps; otherwise, it may worsen the global pandemic [7]. Furthermore, with an Economy that relies on China and other nations, the country cannot afford to close her airspace against countries with confirmed cases, which makes Nigeria vulnerable in the face of the global outbreak [11]. The country situation report (29/2/2020) indicated a confirmed case in quarantine and 24 of his contacts under close observation [6]. Whereas this appeared a commendable effort from the Nigerian government and Nigeria Centre for Disease Control (NCDC), this may have under-estimated the number of contacts with the index case. The infections reported in Germany were linked to a Chinese business partner who was asymptomatic at the time of contact [12]. Three more cases were subsequently linked to the German index and all within a brief contact with him. Hence, all the passengers in the flight that the Nigerian index travelled with should be under close monitoring. Widening the contact tracing will ensure no case is missed with a potential of subsequent spread of the disease in the country.

\section{Laboratory diagnosis}

At the beginning of the epidemic, only two African countries could test and confirm coronavirus disease using realtime polymerase chain reaction (PCR). Today, Nigeria has four centres with the laboratory capacity to confirm the diagnosis of the disease, facilitated by the African Centre for Disease Control and the NCDC $[13,14]$. However, the protocol for appropriate sample collection and transportation should be shared widely with all health care workers.

\section{Training and Manpower development}

The NCDC released policy guidelines on Covid-19 with regular updates. However, there is an urgent need to train the clinicians across all levels on the early recognition of the Covid-19 cases. The healthcare training could be achieved by the NCDC in-collaboration with the Federal Ministry of Health (FMOH) and other relevant stakeholders. The approach of deploying personnel from NCDC to the affected states is plausible, but may become overwhelming when the number of cases increases in a state or when many states are involved in the country. Hence, strengthening of the state capacity through training of foci people who could go ahead to train other health care workers. This training should take place during this window of opportunity when there is no new confirmed case besides the index case (as of the 2nd March 2020) [14]. Also, there are free online courses developed by the WHO, Nigerian clinicians need to take the courses and build their capacity as the website showed no African nation was among the top ten nations that have taken the courses so far.

\section{Funding}

The Nigerian government approved $\$ 2.3$ million (860 million Naira) for the management of coronavirus in the wake of the epidemic. While this is a positive development, it is grossly inadequate to fund the outbreak response, especially with the large population at risk. The Nigerian government could at this period of epidemic approach donor agencies including individual philanthropists for donations towards the country's course in fighting against the diseases [14]. The fund should be judiciously utilized, with transparency and accountability.

\section{Information management}

The role of the media in the dissemination of correct information to her citizenry is crucial. This step will ensure calmness and avoid unnecessary panic in the face of the global threat [15]. Few days after the confirmation of the index, false information regarding the index case dominated the media and it took the relevant agencies a couple of hours to refute the information. The media team for the Covid-19 should be under a national ad-hock task force, who should issue correct information relating to the epidemic to the community. Also, there should be active monitoring of social media in order to quickly identify and dispel false information and myths. The positive aspect of social media should be well utilized. 


\section{Data and research}

Without appropriate data gathering and investment in research, halting the global spread of coronavirus will be difficult and almost impossible. The sequence of the viral genome of Covid-19 within the shortest time enabled the sharing of the information that allowed other countries to diagnosis the disease [2]. The reports of the clinical profile of infected individuals have also helped in identifying those at risk. The Nigerian government and the NCDC should support local research that will help in understanding the dynamics of the disease in Nigeria. Besides, there should be sharing of the obtained data with the relevant authorities and stakeholders for appropriate response.

\section{Conclusion}

Nigeria, with an estimated population of 200 million and a weaker health system, is at risk of worsening the current global pandemic of Covid-19. The recently confirmed index case should be handled appropriately, and the control of the epidemic may benefit from some of the suggestions above.

\section{References}

1. H. Lu, C. W. Stratton, Y. W. Tang. Outbreak of pneumonia of unknown etiology in Wuhan, China: The mystery and the miracle. J. Med. Virol. 2020; 92:401-402. https://doi.org/10.1002/jmv.25678

2. D. S. Hui et al. The continuing 2019-nCoV epidemic threat of novel coronaviruses to global health — The latest 2019 novel coronavirus outbreak in Wuhan, China. Int. J. Infect. Dis. 2020; 91:264-266. https://doi.org/10.1016/j.ijid.2020.01.009

3. Coronavirus Situation Report, "Coronavirus disease 2019 ( COVID-19)" 2020.

4. T. Lancet and I. Diseases, “Challenges of coronavirus disease 2019”. Lancet Infect. Dis. 2020; 2019(20):30304. https://doi.org/10.1016/ S1473-3099(20)30072-4

5. A. R. Sahin et al. 2019 Novel Coronavirus (COVID-19) Outbreak : A Review of the Current Literature. EJMO. 2020; 4(1):1-7. https:// doi.org/10.14744/ejmo.2020.12220

6. Nigeria Centre for Disease Control, "First case of coronavirus disease confirmed in Nigeria" 2019. [Online]. Available: https://www. ncdc.gov.ng/news/227/first-case-of-corona-virus-disease-confirmed-in-nigeria. [Accessed: 02-Mar-2020].

7. M. Moore, B. Gelfeld, A. Okunogbe, C. Paul. Identifying Future Disease Hot Spots: Infectious Disease Vulnerability Index. 2019; Santa Monica, Calif: Rand Corporation, 2017.

8. C. Huang et al. Clinical features of patients infected with 2019 novel coronavirus in Wuhan, China. Lancet. 2020; 395(10223):497-506. https://doi.org/10.1016/S0140-6736(20)30183-5.

9. N. Chen et al. Epidemiological and clinical characteristics of 99 cases of 2019 novel coronavirus pneumonia in Wuhan, China: a descriptive study. Lancet. 2020; 395(10223):507-513. https://doi.org/10.1016/S0140-6736(20)30211-7.

10. Q. Li et al. Early Transmission Dynamics in Wuhan, China, of Novel Coronavirus-Infected Pneumonia. N. Engl. J. Med. 2020 ; 1-8. https://doi.org/10.1056/NEJMoa2001316.

11. I. I. Bogoch, A. Watts, A. Thomas-Bachli, C. Huber, M. U. G. Kraemer, K. Khan. Pneumonia of unknown aetiology in Wuhan, China: potential for international spread via commercial air travel. J. Travel Med. 2020; 1-3. https://doi.org/10.1093/jtm/taaa008.

12. C. Rothe et al. Transmission of 2019-nCoV Infection from an Asymptomatic Contact in Germany. N. Engl. J. Med. $2020 ; 2019-2020$. https://doi.org/10.1056/nejmc2001468.

13. Nigeria Centre for Disease Control, "Frequently ask questions on coronavirus," 2020. [Online]. Available: https://www.ncdc.gov.ng/ news/232/frequently-asked-questions-on-coronavirus---29\%2F02\%2F20. [Accessed: 02-Mar-2020].

14. J. N. Nkengasong and W. Mankoula. Comment Looming threat of COVID-19 infection in Africa : act collectively, and fast. Lancet. 2020; 6736 (20):19-20. https://doi.org/10.1016/S0140-6736(20)30464-5.

15. COVID-19: fighting panic with information. Lancet. 2020; 395 (10224):537. https://doi.org/10.1016/S0140-6736(20)30379-2 .

How to cite this article: Olayinka R. Ibrahim, Yetunde T. Olasinde. Coronavirus Disease (COVID-19) in Nigeria: Mitigating the Global Pandemic. J Clin Med Kaz. 2020; 1(55):36-38 